\section{Another delay for BNFL}

Gillian Boucher reports on the latest developments in the controversy over the reprocessing of nuclear fuel

Just when they seemed about to gel British reprocessing plans have received a vigorous stir from $\mathrm{Mr}$ Shore, the Secretary of State for the Environment, who announced last week that planning permission for expansion at Windscale was to be witheld until he had given it more thought. Cumbria County Council had given British Nuclear Fuels Ltd (BNFL) a provisional go-ahead on November 2 but as the application was outside the scope of the county's development plan it had to be referred to Mr Shore.

If he had done nothing the application would have received automatic approval after three weeks. It was agreed at an inter-departmental meeting on November 15 that $\mathrm{Mr}$ Shore would not call in the plans. On the last day on which he could intervene he said he needed more time; by last weekend the House of Commons Select Committee on Science and Technology was considering whether to take up the issue and question $\mathrm{Mr}$ Shore itself.

Mr Shore has two choices: handing the matter back to the county council, which virtually means accepting it, as the county council was "minded to approve" the application; or calling it in for his own decision, which will probably mean either a public enquiry or a Planning Inquiry Commission and a delay of at least a year.

BNFL wants to expand and update its Magnox repinocessing plant, develop the process of vitrification of nuclear waste, and build a new "Thorp" plant for reprocessing oxide fuels. It is this last which arouses such passion because of the large amounts of foreign fuel that it would reprocess. Although it means 1,000 new jobs and around $£ 500$ million in earnings from deals with Japan, Germany and Sweden already in advanced stages of negotiation, it also carries the dangens inherent in purifying and transporting plutonium. Friends of the Earth feel that the plutonium peril is so great that oxide fuel should not be reprocessed; but a BNFL spokesman says that although oxide fuel is not as susceptible to corrosion as Magnox fuel, corrosion and leaks into the water in storage tanks will eventually occur if the fuel is not reprocessed.

Mr Shore probably "decided not to decide" as a result of strong pressure for a public enquiry from environmentalist groups. But what he wants more time for is not at all clear. $\mathrm{He}$ may want to talk to more specialists or learn the views of $\mathrm{Mr}$ Carter. Some critics fear that he is merely waiting for the interest built up over recent weeks to die down before giving his verdict.

He has reserved his decision on the whole of the planning proposal, not merely the oxide plant. But the reprocessing of Magnox fuel cannot be delayed and according to BNFL a refusal on that would result in the premature closure of the Magnox nuclear power stations. A decision on the oxide plant is not as urgent because spent oxide fuel can be stored, but Britain already has two oxide-consuming AGR reactors in action. A ban on oxlide reprocessing would force Britain to take its oxide fuels elsewhere for reprocessing and mean the loss of potential foreign business.

Though nobody would deny the gravity of the problems involved, BNFL is understandably irritated that the government should be stalling 8 months after giving it permission to seek foreign deals-permission which was supposed to have been preceded by adequate debate of the issues. And $\mathbf{J}$. C. C. Sterwart, Deputy Chairman of the Nuclear Power Company, said at a British Nuclear Forum Conference last week that it would be "absolutely appalled if the matter did not go forward".

One possible further hurdle, though, lies in the financing of the oxide plant. Last July the government approved BNFL's proposed investment in the Magnox fuel plant and vitrification development, but it has not yet decided whether to act as the lender of last resorit for the oxide plant. Most of the finance, however, would come from prepayments from the foreign countries with whom the deals are being negotiated.

Meanwhile the Cumbria council itself may not be allowed quickly to forget its decision. Firiends of the Earth and the Lawyers' Ecology Group believe that it behaved improperly in not considering such aspects of the application as the transport of nuclear fuels and the build-up of radioactivity. $\mathrm{Mr}$ Shore had written to the council confirming that these were matters for the government, but according to the Lawyers' Ecology Group this does not absolve the county council of its duty to consider the questions. Several pressure groups are likely to come together to take legal action against the council if the planning application is not called in.

\section{Animal anxieties}

Britain's Medical Research Council (MRC) found it necessary to release a statement last week in an effort to quell a growing storm at its Laboratory Animals Centre at Carshalton, Surrey. The row is over the MRC plan to charge the 70 animal breeders participating in a 26-year-old accreditation scheme the full economic costs of the $£ 70,000$ service provided.

The Council said it reaffirmed the importance it attached to its policy, but said it "has been made aware" of the problems in relation to charging for the scheme and had therefore set up a committee with the "necessary powers to act" to review these urgently. It is thought that the committee could report in weeks rather than months.

Last week, however, delegates from nine trade unions represented at the Carshalton centre called a press conference just as the Council itself was about to meet. They said that if as they expected the Council decided to set up a working party they would have no confidence in this as it was "not a way to proceed". Industrial action was being contemplated, and one union had already asked the Minister of Education and Science to intervene.

The scheme is voluntary and consists of grading, by their degree of freedom from microorganisms, some 3 million anlimals used every year for research and teaching in labs up and down the country. The unions say the scheme is now in danger of breaking down totally because the majority of breeders, apparently unable to afford the charges, are threatening mass resignation.

This, they say, would result in "the loss of public control over the commercial breeding of laboratory animals" and could cost the community more than it saves insofar as the use of non-accredited animals grows and leads to costly outbreaks of disease that might not otherwise occur. There is no clear sign, however, that the MRC actually wants the scheme to end, and it seems likely that the new committee will seek ways to maintain it while introducing charges.

Chris Sherwell 